\title{
Putting patients before patents
}

\author{
James P. Evans, MD, PhD
}

G enetics in Medicine is privileged to publish a special online-only supplement that focuses on the issue of gene patents, licenses, and their impact on patient access to genetic tests. ${ }^{1}$ This special Genetics in Medicine issue consists of a series of eight case studies on 10 clinical conditions undertaken by a team of faculty, students, and research staff from Duke's Center for Public Genomics ${ }^{2}$ in an effort to examine both benefits and harms that result from current patenting and licensing practices in the field of genetic diagnostics. They are the culmination of 2 years of study by the Duke team, lead by Robert Cook-Deegan, and consist of deep analyses of 10 clinical conditions that were carefully selected to illuminate, as far as possible, a field in which there has been considerable heat but little light. The work was undertaken at the behest of the Secretary's Advisory Committee on Genetics, Health and Society (SACGHS), a Federal committee whose charge is to provide advice and recommendations to the Secretary of Health and Human Services. Each of the case studies was carefully selected to represent "experiments of nature" in which the effects of gene patents and licenses could be isolated and, when possible, quantified.

It is an auspicious time for these studies to be published. The issue of gene patents is at the heart of several pending legal battles, including a case against Myriad Genetics that asserts that genes are not legitimately patentable material and that the enforcement of such patents is unconstitutional. Adding further fuel to the controversy swirling around the issue of gene patents, the SACGHS has recently released its report on the impact of gene patents on patient access to diagnostic tests. ${ }^{3}$ Four years in the making and based, in part, on the studies of the Duke team, the report calls for legislation that would make those who use patented genes for research or medical diagnosis exempt from claims of infringement. The recommendations to the secretary also advocate putting "teeth" into current guidelines such as those of the National Institutes of Health that encourage, but do not mandate, nonexclusive licensing of genetic tests.

The time is ripe for a thorough examination of gene patents for another reason as well. We are poised on the brink of exciting times in medicine. There is much anticipation that robust analysis of our individual genomes will illuminate a great deal about the fundamental basis of disease, provide promising novel drug targets, and usher in a new age of individualized medicine. But, as documented in the case studies and the SACGHS report, there is a concern that fragmented ownership of the genome will interfere with the genomic analyses critical to such application. When rights to the human genome are fragmented to the point that thousands of genes are "owned" by myriad parties (pun intended), how will we hack our way through the resultant thicket to facilitate the application of

From the Department of Genetics, University of North Carolina, Chapel Hill, North Carolina.

James P. Evans, MD, PhD, University of North Carolina, Campus Box 7264, Chapel Hill, NC, 27599-7264. E-mail: jpevans@med.unc.edu.

Disclosure: The author is a member of SACGHS and was chair of the task force which addressed the gene patent issue.

DOI: 10.1097/GIM.0b013e3181d79ee1 multiplex genotyping, multiplex sequencing, and whole genome sequencing?

The case studies and the SACGHS report demonstrate a number of harms that result from gene patents in the diagnostic arena. These harms are most clearly seen when an exclusive (or no) license is issued by a patent holder, resulting in only a single laboratory that is allowed to perform a given test. In such circumstances, patient access to testing can suffer, most clearly when exclusive providers fail to contract with insurers such as state Medicaid programs, leaving patients without the option of a given genetic test should it be recommended by their provider. Other harms of exclusivity include an inability to obtain secondopinion testing and concerns over quality, given that the most robust means of quality assurance are not available in the context of a single provider. The case studies and the SACGHS report also document that laboratories are already choosing not to report medically relevant test results for patented genes included within multiplex tests. As one would expect, when only a single laboratory is allowed to engage in diagnostic testing, clinicians who are concerned about a particular laboratory have no recourse in their choice of laboratories, and it is the laboratory, rather than patients and providers, who define the terms of testing.

The case studies also suggest that gene patents and the lure of exclusivity are not needed for the development and wide availability of genetic diagnostic tests. The case of cystic fibrosis is instructive. When the laboratories of Lap-Chee Tsui and Francis Collins first cloned the CFTR gene, they worked to ensure broad licensing. What we see now two decades later are dozens of laboratories - both private and public - that compete on the basis of service, innovation, and quality. Indeed, in no case that was studied was a holder of exclusive intellectual property rights to a gene the first to develop a test. Rather, intellectual property rights are typically invoked only after numerous laboratories have already developed testing and then are used to clear the market of competition.

The case studies also reveal some surprises. Most of us would have suspected that patent-enabled exclusivity of a gene would result in a significantly increased cost of testing. However, for most situations, there was little evidence to support such a contention. For example, in the case of $B R C A 1 / 2$ - which are, of course, exclusively controlled - the cost (when adjusted as price per amplicon) for comprehensive mutational analysis does not exceed that of other similar tests not under patent or exclusive license arrangements. Another surprise to some will be that although we at universities are often fond of projecting a squeaky clean image, we are part of the problem; the practice of issuing exclusive licenses is commonly pursued by many university technology transfer offices.

The case studies attempt to shed light on an area that has been severely lacking in real and interpretable data. They do a superb job of that and are even-handed, documenting benefits and harms from patents. But policy is always a matter not only of accruing data but also of interpreting it. If that were not the case, there would be no such thing as policy disagreements - for in the end, we all have access to the same data. However, as evidenced by the existence of blue states and red states, we 
often seem to come to different conclusions. Good and wellintentioned people will sometimes disagree about proper policy when looking at identical evidence. Such is clearly the case in the realm of gene patents.

Because both benefits and harms might be invoked with regard to gene patents, what should be our yard stick for weighing them and ultimately making policy decisions? I would maintain that the rules are somewhat different for health-related entities than they are for mere commodities such as consumer electronics and that even a modest degree of harm-especially in the context of little documented benefit-is sufficient to consider tailored and specific policy changes. In the end we must ask ourselves whether a given policy is ultimately in the best interests of patients. After all, while the patent system certainly seeks to harness business models and economic self-interest, it does so for the express purpose of furthering "progress in science and the useful arts."4 The recommendations of the SACHGS report seek to strike a balance, allowing the patent incentive to work in areas where it might be necessary (e.g., therapeutics) but disallowing it where it is not needed and may well be doing more harm than good, such as in the case of diagnostics.

Genetics in Medicine is proud to publish these landmark studies, which illuminate so much in a field filled with opacity and heated rhetoric. Regardless of future court decisions and policy deliberations, these cases will be looked upon for years to come as a milestone in our understanding of biological intellectual property and its application.

\section{REFERENCES}

1. Evans JP, ed. Patently complicated: case studies on the impact of patenting and licensing on clinical access to genetic testing in the United States. Genet Med 2010;12(suppl):S1-S211.

2. Duke's Center for Public Genomics. Cofunded by NHGRI and US Department Energy P50 HG 003391. The Duke Center for Public Genomics is part of the Duke Institute for Genome Sciences and Policy.

3. SACGHS report. Available at: http://oba.od.nih.gov/oba/SACGHS/SACGHS $\%$ 20Patents\%20Report\%20Approved\%202-5-20010.pdf. Accessed date March 5, 2010.

4. US Constitution, Article 1, section 8 